\title{
Морис Мерло-Понти
}

\section{Смисъл и не-смисъл Съмнението на Сезан}

„Смисъл и не-смисъл“ (Sens et non-sens) е първият обхватен сборник, който Морис МерлоПонти публикува през 1948 г. в Editions Nagel. Тройното разпределение на темите, посветени на изкуство, философия и политика, се задържа чак до последната му, посмъртно публикувана книга „Видимото и невидимото“ (1964). По подобен начин специфичната му теория на изкуството се подхранва от неспирен интерес към живота и творчеството на Сезан. Ето защо линията на феноменологичната естетика, създадена върху богатите източници на Декарт, Кант, Хегел, Бергсон, Пол Валери, екзистенциалистите, ясно се проследява от „Съмнението на Сезан“ (първото есе в „Смисъл и не-смисъл“) чак до последното есе „Окото и духът“ от 1961 г.

Съмнението на Сезан е референтен текст за всяка философия заради предизвикателно поставените въпроси в максимално широкия кръг от психоанализа и дълбинна психология до онтологията на изкуството и осъзнаването на смисъла, предопределението и свободата, родени при контакта на вътрешния и външния свят на човека. Със Съмнението продължаваме да се питаме: Кое е това всичко, което носи малката дума „виждам“? Как да разбираме позитивния смисъл на творчеството? Какво е онова „по-загадъчно, което се заплита в самите корени на битието“? В Похвала на философията (от 1953 г.) Мерло-Понти ще каже, че в тези ценни моменти се възобновява, продължава не само философията, но и животът на всеки човек.

Проф. Лидия Денкова

Необходими са му били сто работни сеанса за един натюрморт, сто и петдесет сеанса с позиране за един портрет. Онова, което ние наричаме негово творчество, той смята само за опит и доближаване до собствената си живопис. През септември 1906 г., когато е на 67 години, и само месец преди да умре, той пише: „В състояние съм на такива мозъчни смущения, толкова е голямо безпокойството ми, че в един момент повярвах, дето слабият ми разум ще ме напусне... Сега, струва ми се, съм по-добре и по-точно се ориентирам в моите изследвания. Дали ще постигна тъй дълго търсената и преследвана цел? Продължавам да се осланям на природата в моите проучвания и смятам, че малко по малко напредвам“. Живописта е била неговият свят и неговият начин на съществуване. Той работи сам, без ученици, без възхищението на своето семейство, без окуражаване от страна на критиците. Рисува в следобеда на същия ден, когато е починала майка му. През 1870 г. рисува в Естак, докато 16 жандарми го издирват за отклонение от военната служба. И все пак му се случва да постави под съмнение това призвание. Остарявайки, се пита дали новата му живопис не се 
дължи на нарушено зрение, дали целият му живот не се е основавал на претърпян от тялото му инцидент. На това усилие и на съмнението отговарят недоверчивостта или глупостите на неговите съвременници. „Живопис на пиян каналджия“, казва един критик през 1905 г. Днес G. Mauclair все още извлича аргумента си срещу Сезан от собствените му признания в безсилие. По това време картините му са се разпространили по света. Защо има толкова несигурност, толкова мъчителен труд, толкова провали - и изведнъж най-голям успех?

Зола, приятелят на Сезан от детството, е първият, който открива в него гениалност и за пръв път говори за него като „несполучил гений“. Зола е наблюдавал живота на Сезан с повече внимание към характера му, отколкото към смисъла на неговата живопис, така че е можел да я разглежда като болестно проявление. Защото още от 1852, когато постъпва в колежа Бурбон в Екс, Сезан създава безпокойство у приятелите си с изблиците на гняв и депресиите си. Седем години по-късно той е решен да стане художник, но се съмнява в таланта си и не смее да поиска от баща си, шапкар и после банкер, да го изпрати в Париж. В писмата си Зола го упреква в нестабилност, слабост, нерешителност. Сезан пристига в Париж, но пише: „Смених единствено мястото и мъката ме последва“. Той не понася разискването, защото го уморява и не знае как да изложи основанията си. Тревожността е в основата на характера му. На четиридесет и две години мисли, че ще умре млад, и съставя завещание. На четиридесет и шест години в продължение на шест месеца е разтърсван от бурна, мъчителна, съсипваща страст, чиято развръзка остава неизвестна и за която той никога не говори. На петдесет и една години се оттегля в Екс, за да открие природата, която по-добре отговаря на неговия гений, но това също е самозатваряне в мястото на неговото детство, майка му и сестра му. Когато майка му умира, той се обляга на сина си. „Животьт е ужасен“, казва често. Отдава се на религията, която за него започва със страха от живота и страха от смъртта. „Страх ме е, обяснява той на един приятел, чувствам се все още за четири дена на земята; а после? Вярвам, че ще го преживея, и не искам да рискувам и да се пържа за вечността“. Религиозността му по-късно се задълбочава, но първичният подтик е била нуждата да прикрепи някъде живота си и така да се отърве от него. Става все по-саможив, подозрителен и чувствителен. Понякога идва в Париж, но когато среща приятели, отдалеч им прави знак да не го доближават. Когато през 1903 г. неговите картини започват да се продават в Париж два пъти по-скъпо от тези на Моне и младежи като Йоаким Гаске и Емил Бернар отиват да го видят и разпитват, той малко се отпуска. Но гневните му изблици продължават. Навремето минаващо наблизо дете го е ударило в Екс и оттогава той не може да понася никакъв контакт. Един ден, когато е стар, губи равновесие и Емил Бернар го задържа с ръка. Сезан силно се разгневява. Чуват го как крачи из цялото ателие, крещейки, че няма да се остави „да го заковат“. Пак заради „заковаването“ той отстранява от ателието си жените, които могат да му служат като модели, от живота си отстранява свещениците, които нарича „лепки“, от ума си теориите на Емил Бернар, когато стават твърде натрапчиви. Загубата на ґъкави контакти с хората, безсилието да овладява новите ситуации, бягството в навиците и в среда, която не поставя проблеми, непреклонното противопоставяне на теорията и практиката, на „заковаването“ и една свобода на самотник - всички тези симптоми позволяват да се говори за болестно състояние, 
например както при Ел Греко, за шизоидност. Идеята за живопис „по природата“у Сезан идва от същата слабост. Неговото изключително внимание към природата, към цвета, нечовешкият характер на живописта му (казвал, че лицето трябва да се рисува, както се рисува предмет), пълната му отдаденост на видимостта са само бягство от света на хората, отчуждение от неговата човешкост.

Тези предположения не дават позитивния смисъл на творчеството, само от тях не може да е заключи, че живописта му е декадентски феномен, и както казва Ницше, феномен на „обеднял“ живот, или пък че успелият човек няма какво да научи от нея. Вероятно Зола и Емил Бернар са отделили твърде много място на психологията и на личното си познанство със Сезан, та са повярвали в провала. Остава възможността заради невротичните си слабости Сезан да е породил една валидна за всички форма на изкуството. Оставен на себе си, той е можел да гледа природата така, както само един мъж може. Смисълът на неговото творчество не може да бъде определен от живота му.

Не бихме познали този смисъл по-добре посредством историята на изкуството, тоест ако го отнесем към влиянията (влиянията на италианците и Тинторето, Дьолакроа, Курбе и импресионистите), към начина, по който Сезан подхожда към живописта, или дори към собственото му свидетелство. Първите му картини, чак до 1870 г., са нарисувани сънища, едно Отвличане, едно Убийство. Те идват от чувствата и искат да провокират най-напред чувства. Почти винаги са нарисувани в едри черти и предават по-скоро моралната физиономия на жестовете, отколкото видимия им аспект. Навярно от импресионистите и по-специално от Писаро Сезан е започнал да разбира живописта не като въплъщение на въобразени сцени, външно проектиране на сънища, а като точно изучаване на привидностите, не толкова като работа в ателие, колкото като работа по природа; така изоставя бароковия начин на изпълнение, който най-напред търси да предаде движението за сметка на малките, поставени една до друга мазки и търпеливите щрихи.

Сезан обаче бързо се отделя от импресионистите. Импресионизмът иска да вложи в живописта начина, по който обектите поразяват очите ни и въздействат на сетивата ни. Той ги представя в атмосферата, където ни биват дадени от моментното възприятие, без абсолютни контури, свързани помежду им чрез светлината и въздуха. За да се предаде тази светлинна обгърнатост, трябва да се изключат земните цветове, охрата, черното и да се използват само седемте цвята на призмата. За да се представи цветът на обектите, не е достатъчно да се нанесе на платното техният локален тон, тоест цветът, който обектите приемат, ако бъдат изолирани от всичко заобикалящо; трябва да се държи сметка за явленията на контраст, които в природата видоизменят локалните цветове. Нещо повече - всеки цвят, който виждаме в природата, поради известно отражение провокира виждането на допълнителния цвят и тези допълнителности се разрастват. Следователно, за да се получи върху платното онова, което ще се види в слабата светлина на апартаментите, самият аспект на цветовете под слънцето, на платното трябва да фигурира не само зелено, ако става дума за трева, а също допълнителното червено, което ще го накара да вибрира. В крайна сметка самият локален тон е декомпозиран при импресионистите. Всеки цвят, общо взето, може да се получи, като съставните цветове се полагат един до друг, вместо да се смесват, което дава далеч по-трептящ тон. В резултат от 
тези похвати платното, което вече не можело да се сравнява с природата в отделните пунктове, възпроизвеждало чрез действието на съединените една връз друга части общата истина на впечатлението. Но същевременно нарисуваната атмосфера и разделението на тоновете създавали нов обект, включително чрез заличаване на собствената му тежест. Композицията на палитрата на Сезан ни кара да предположим, че той си поставя друга цел: има ги не седемте цвята на призмата, а осемнадесет цвята, шест червени, пет жълти, три сини, три зелени, едно черно. Използването на топлите цветове и черното показва, че Сезан иска да възпроизведе обекта, да го преоткрие зад атмосферата. Той се отказва също от разделянето на тона и го замества с надградени смесвания чрез разстилане на хроматични нюанси върху обекта, чрез цветова модулация, която следва формата и получената светлина. Премахването на точните контури в някои случаи, приоритетът на цвета спрямо рисунъка очевидно нямат един и същ смисъл при Сезан и импресионизма. Обектът вече не е покрит с отблясъци, изгубен във връзките си с въздуха и другите обекти, той сякаш е смътно осветен отвътре, светлината се излъчва от него и така се създава впечатление за здравина и материалност. Впрочем Сезан не се отказва да накара топлите цветове да вибрират, постигайки това цветово усещане с употребата на синьо.

Би трябвало в този случай да кажем, че той е поискал да се върне към обекта, без да напуска естетиката на импресионизма, която взима образеца от природата. Емил Бернар му напомнял, че за класиците една картина изисква очертание с контури, композиция и разпределение на светлините. Сезан отговарил: „Те са правели картина, а ние опитваме едно парче от природата“. За майсторите казал, че „са замествали реалността с въображението и съпровождащата го абстракция“, а за природата - че „трябва да се поклоним пред това съвършено творение. От него ни идва всичко, чрез него съществуваме, да забравим всичко останало“. Сезан твърди, че е поискал да направи от импресионизма „нещо солидно като изкуството на музеите“. Живописта му вероятно е парадокс: да търси реалността, без да изоставя усещането, без да се ръководи от друго освен от природата в непосредственото впечатление, без да очертава контури, без да поставя в рамка цвета чрез рисунъка, без да композира перспективата или картината. За Бернар това е самоубийството на Сезан: стреми се към реалността и си забранява начините да я постигне. Тук би се открила и причината за трудностите, а така също за деформациите, които се откриват у него, най-вече между 1870 и 1890 година. Чиниите или купите, поставени странично върху маса, би трябвало да са елипси, но двата върха на елипсата са уголемени и разтегнати. Работната маса в портрета на Гюстав Жофроа се излага на показ в долния край на картината против законите на перспективата. Откъсвайки се от рисунката, Сезан навярно е потъвал в хаоса на усещанията. А усещанията са преобръщали обектите и са внушавали постоянно илюзии, както го правят понякога - например илюзията за движение на обектите, когато мърдаме главата си. Ако съждението не е поправяло непрекъснато привидностите, Сезан е щял, казва Бернар, да потопи „живописта в невежеството и ума си в мрака“. В действителност така може да съди за живописта му само някой, който пропуска половината от това, което е казал, и си затваря очите за това, което е нарисувал. От диалозите с Емил Бернар е ясно, че Сезан винаги се стреми да избяга от готовите алтернативи, които му предлагат - алтернативите на сетивата или тези на ума, от художника, който гледа, и художника, който мисли, от природата и от композицията, 
от примитивизма и традицията. „Необходимо е да се създаде оптика“, казва той, но „под оптика разбирам логическа визия, сиреч без нищо абсурдно“. „За нашата природа ли става дума?“, пита Бернар. Сезан отговаря: „Става дума за двете“. - „Природата и изкуството не са ли различни?“ - „Бих искал да ги обединя. Изкуството е лична аперцепция. Поставям тази аперцепция в усещането и искам от ума да я организира в творба." Но дори тези формули отделят много място на обичайните понятия „чувствителност“ или „усещане“ и „ум“. Ето защо Сезан не е убедителен и предпочита да рисува. Вместо да прилага в творчеството си дихотомии, които впрочем принадлежат повече на традициите на дадена школа, отколкото на основателите - философи или художници - на тези традиции, той би желал повече буквално да се учи от своята живопис, което значи да ги поставя под въпрос. Сезан не е смятал, че трябва да избира между усещане и мислене, също както между хаос и ред. Той не иска да отделя неподвижните неща, които се появяват пред нашия поглед, от убягващия начин на появата им, иска да рисува материята в процеса на придобиване на форма, раждащия се ред от една спонтанна организираност. За него не съществува прекъснатост между „сетивата“ и „ума“, прекъсване има между спонтанния ред на възприетите неща и човешкия ред на идеите и науките. Ние възприемаме нещата, договаряме се по тях, закотвени сме в тях и върху тази „природна“ основа градим науки. Сезан е поискал да нарисува първичния свят и затова картините му създават впечатление за първоначалната природа, докато фотографиите на същите пейзажи подсказват за работата на хората, за техните удобства и неотменно присъствие. Сезан никога не е искал да „рисува като животно“, искал е да постави отново интелигентността, идеите, науките, перспективата, традицията в контакт с природния свят, понеже те са предназначени да го разбират; искал е, както казва, да сблъска „науките, произлезли от природата“, със самата природа. Верни на явленията, търсенията на Сезан в перспективата разкриват онова, което психологията неотдавна формулира. Преживяната перспектива, перспективата на нашето възприятие не е геометричната или фотографската: във възприятието близките обекти изглеждат по-малки, а отдалечените обекти - по-големи, което не става при фотографията - виждаме го в киното, когато наближава влак и се уголемява много по-бързо, отколкото реалният влак в същите условия. Да се каже, че един видян косо кръг се вижда като елипса, означава да се подмени действащото възприятие със схемата на онова, което би трябвало да видим, ако бяхме фотографски апарати: в действителност ние виждаме форма, която трепти около елипсата, без да е елипса. В един портрет на госпожа Сезан фризът на тапицерията от едната и другата страна на тялото не е права линия: известно е обаче, че ако една линия минава под широка хартиена лента, двете видими части на линията изглеждат разместени. Масата на Гюстав Жофроа се разполага в долния край на картината, но когато окото ни пробягва по широка повърхност, образите, които добива, един след друг се хващат от различна гледна точка и така цялостната повърхност се изкорубва. Вярно е, че пренасяйки върху платното тези деформации, аз ги карам да замръзнат, спирам спонтанното движение, чрез което те се трупат една връз друга във възприятието и теглят към геометричната перспектива. Същото става по отношение на цветовете. Една роза върху сива хартия оцветява фона в зелено. Школската живопис рисува фона в сиво, разчитайки, че подобно на реалния обект картината ще 
произведе ефекта на контраста. Импресионистичната живопис слага зелено на фона, за да получи също толкова жив контраст като обектите под открито небе. Дали по този начин не фалшифицира връзката на цветовете? Би било така, ако стигаше само дотук. Но един художник може подходящо да модифицира всички други цветове на картината и те да отнемат на зеленото върху фона характера на реален цвят.

По същия начин геният на Сезан подрежда цялата картина така, че деформациите в перспективата престават да са видими сами по себе си, когато се гледат общо, и само спомагат, както става при естественото виждане, да се създаде впечатлението за един раждащ се ред, за обект в процес на поява, който се събира пред погледа ни. Също така контурът на обектите, схванат като очертаваща ги линия, принадлежи не на видимия свят, а на геометрията. Едно нещо е да се отбележи контурът на ябълка с една черта, докато всъщност той е идеалната граница, към която страните на ябълката бягат в дълбочина. Ако не се отбележи никакъв контур, обектите ще загубят идентичността си. Ако се отбележи само един, ще бъде пожертвана дълбочината, тоест измерението, което ни дава нещото не като изложено пред нас, а като изпълнено с вътрешни запаси и като неизчерпаема реалност. Ето защо Сезан следва в цветова модулация издуването на обекта и нанася със сини черти множество контури. Погледът, който се мести от единия към другия, схваща контура, раждащ се сред всички други, също както става във възприятието. Тези прочути деформации съвсем не са случайни. Впрочем Сезан се отказва от тях в последния период след 1890 г., когато вече не изпълва платното си с цветове и изоставя сбитото пресъздаване на натюрмортите.

Следователно рисунката трябва да е резултат от цвета, ако желанието е светьт да бъде предаден в цялата му плътност, защото той не е нищо определено, няма лакуни, един организъм от цветове, пресичани от пробягващата перспектива, контурите, правите, кривите, които се налагат като силови линии. Така кадърът на пространството се изгражда, като вибрира. „Рисунъкът и цветът вече не се различават; рисуването става, докато се нанасят цветовете; колкото повече цветът се хармонизира, толкова по-точна става рисунката... Когато цветът постигне цялото си богатство, формата е в своята пълнота“. Сезан не търси да подскаже чрез цвета тактилните усещания, които биха предали формата и дълбочината. В първичното възприятие разликите между осезанието и зрението са непознати. Познаването на човешкото тяло ни учи впоследствие да различаваме сетивата си. Преживяното нещо не се открива или построява въз основа на данните от сетивата, а се предлага наведнъж като център, откъдето те се излъчват. Ние виждаме дълбочината, гладкостта, мекотата, твърдостта на обектите - Сезан казва дори: техния мирис. Ако художникът иска да изрази света, трябва подредбата на цветовете да носи в него това неделимо Цяло; в противен случай живописта му ще бъде алюзия за нещата и няма да ги предаде в тяхната всевластна единност, в присъствието, в ненадминатата пълнота, която за всички нас е определението на реалността. Затова всяко нанасяне на цвета (touche) трябва да удовлетворява безброй условия, затова Сезан понякога размишлява в продължение на час, преди да го направи, то, както казва Бернар, трябва да „съдържа въздуха, светлината, обекта, плана, характера, рисунката, стила“. Изразяването на това, което съществува, е безкрайна задача.

Сезан не пренебрегва физиономията на обектите и лицата, иска само да я хване, когато тя изниква от цвета. Да се рисува лицето „като предмет“ не означава да се 
лиши от неговата „мисъл“. „Художникът разтълкува лицето, той не е глупак - така го разбирам“, казва Сезан. Но това разтълкуване не трябва да бъде мислено отделно от виждането. „Ако рисувам всички малки сини места, малки кестеняви, аз го правя да гледа, както гледа... По дяволите, ако се съмняват как така съчетаването на нюансирано зелено с червено може да направи една уста тъжна или една буза усмихната“. Умът се вижда и се чете в погледите, а те са само оцветени цялости. Другите умове ни се предлагат само въплътени, прилепнали към лице и жестове. Тук няма място различаването на душа и тяло, противопоставянето на мисъл и виждане, защото Сезан се връща именно към изначалния опит, откъдето тези понятия са извлечени и където са неотделими. Художникът, който мисли и търси най-напред изражението, пропуска тайната, възобновяваща се всеки път, щом погледнем някого, и нейната поява в природата. В „Шагренова кожа“ Балзак описва „една... дълга маса, бяла като току-що натрупан пресен сняг, върху която симетрично се издигаха прибори и купчинки от малки златисти хлебчета“1. „През цялата си младост, казва Сезан, исках да нарисувам това, тази маса, бяла като пресен сняг... Сега знам, че трябва да искам да нарисувам единствено: „симетрично се издигаха прибори“ и „малки златисти хлебчета“. Ако нарисувам „купчинки“, съм загубен, разбирате ли? А ако наистина уравновеся и нюансирам по природа моите прибори и хлебчета, бъдете сигурни, че купчинките, снегът и цялото трептене ще бъдат там“.

Ние живеем в среда от предмети, създадени от хората, сред уреди, в къщи, улици, градове и през повечето време ги виждаме единствено през човешките действия, чието приложение те могат да бъдат. Свикваме да мислим, че всичко това съществува необходимо и е непоклатимо. Живописта на Сезан поставя под въпрос тези навици и разкрива дълбината на нечовешката природа, върху която се разполага човекът. Затова неговите персонажи са странни и сякаш са видени от същество от друг вид. Самата природа е лишена от атрибутите, които я подготвят за оживотворяващите причастия: пейзажът е без вятър, водата на езерото в Анеси не помръдва, предметите са смръзнати колебливо като в началото на Земята. Това е неуютен свят без никаква близост, който забранява всяко излияние от страна на човека. Ако човек след картините на Сезан отиде да види други художници, ще почувства облекчение, както подновените разговори след траур прикриват абсолютно новото положение и подкрепят живите. Един-единствен човек обаче е способен на тази визия, която отива чак до корените, отвъд установената човешкост. Всичко показва, че живите създания не знаят как да гледат, да потъват в нещата, без нищо да очакват освен истината. Думите на Емил Бернар, че художникът на реалностите е маймуна, са точно обратното на истината и ние разбираме защо Сезан е можел да подхване наново класическото определение на изкуството: човекът, добавен към природата. Неговата живопис не отрича науката и не отрича традицията. В Париж Сезан всеки ден ходи в Лувъра. Той смята, че живописта се учи, че геометричното изучаване на плановете и формите е необходимо. Осведомява се за геологичната структура на пейзажите. Тези абстрактни връзки би трябвало да действат в акта на живописеца, само че нагласени спрямо видимя свят. Анатомията и рисунъкът присъстват, когато той нанася цвят, както правилата на играта присъстват в тениса. Онова, което

\footnotetext{
${ }^{1}$ Оноре дьо Балзак. Шагренова кожа. С., 1980. Прев. Пенка Пройкова. - Б. пр.
} 
мотивира жеста на художника, не може никога да бъде само перспективата или само геометрията, или законите за разлагането на цветовете, или каквото и да било знание. За всички жестове, които малко по малко създават картината, има един-единствен мотив - пейзажът в неговата цялост и абсолютна пълнота. Тъкмо това Сезан нарича „мотив“. Той най-напред откривал геологичните пластове. После не помръдвал и гледал с разширени очи, казва госпожа Сезан. „Покълвал“ заедно с пейзажа. Целта му била, след като бъде забравена всяка наука, посредством същите науки да се схване наново изграждането на пейзажа като раждащ се организъм. Трябвало отново да се споят всички частични улички, по които поема погледът, да се обедини онова, което се разпръсква заради променливостта на очите, „да се съберат блуждаещите ръце на природата“, казва Гаске. „Една минута - и светът преминава; тази минута трябва да бъде нарисувана в своята реалност“. Така изведнъж секва размишлението. „Държа моя мотив“, казвал Сезан и обяснявал, че обрисуването на пейзажа трябва да не е нито много високо, нито много ниско, или че пейзажът може да се оживи в мрежа, която не пропуска нищо. Тогава той атакувал своята картина от всички страни едновременно, очертавал с цветни петна първия щрих на въглена, геологичния скелет. Образът се насищал, свързвал, изрисувал, уравновесявал, всичко едновременно стигало до зрялост. Пейзажът, казвал той, се мисли в мен и аз съм неговото съзнание. Тази интуитивна наука е далеч от всякакъв натурализъм. Изкуството не е нито подражание, нито впрочем изфабрикуване, следващо желанията на инстинкта или на добрия вкус. Изкуството е действие по изразяване. Също както словото назовава, сиреч схваща в природата си и поставя пред нас в качеството му на разпознаваем обект онова, което е изглеждало смътно, художникът, казва Гаске, „обективира“, „проектира“, „фиксира“. Думата не прилича на това, което означава, но и живописта не е измамлива привидност; по собствените му думи Сезан „пише в живописта това, което още не е нарисувано, и го прави живопис в абсолютен смисъл“. Забравяме хлъзгавите, двусмислени привидности и през тях отиваме право към нещата, които те представят. Художникът подхваща и обръща точно във видим предмет онова, което без него остава затворено в отделния живот на всяко съзнание: вибрацията на привидностите, която е люлката на нещата. За този художник е възможна само една емоция: чувството за странност, единственият поетичен възторг - от винаги започващото отново съществуване.

Леонардо да Винчи приема за девиз строгата точност, всички класически Поетики казват, че творчеството е трудно. Трудностите на Сезан - както тези на Балзак или Маларме - не са от същото естество. Балзак, несъмнено по указанията на Дьолакроа, измисля художник, който иска да изрази самия живот само чрез цветовете и държи скрит своя шедьовър. Когато Френхофер умира, приятелите му не откриват нищо освен един хаос от цветове, неразличими линии, стена от живопис. Сезан бил развълнуван до сълзи, прочитайки „Неизвестният шедьовър“, и заявил, че той самият е Френхофер. От усилието на Балзак, който също е обсебен от „осъществяването“, разбираме усилието на Сезан. В „Шагренова кожа“ той говори за една „мисъл, която трябва да се изрази“, за „система, която трябва да се построи“, за „наука, която трябва да се обясни“. Той кара Луи Ламбер, един от неуспелите гении в „Човешка комедия“, да каже: „Вървя към някакви открития... но какво име да дам на силата, която ми връзва ръцете, затваря ми устата и ме повлича в посока, обратна на моето призвание?“ Не е достатъчно да се каже, че Балзак си е поставил за цел да разбере съвременното му общество. Да се 
опише типът на търговския пътник, да се направи „анатомия на учителското тяло“ или дори да се поставят основите на една социология не е било свръхчовешка задача. След като са назовани видимите сили, като парите и страстите, и тяхното явно действие е описано, Балзак се пита за какво е всичко това, каква е причината да съществуват, какво означава например тази Европа, „чиито усилия са насочени към не знам каква тайнствена цивилизация", онова, което поддържа вътрешно света и кара видимите форми да се множат“. За Френхофер смисълът на живописта е същият: „... Ръката не принадлежи само на тялото, тя изразява и продължава една мисъл, която трябва да се схване и предаде... Истинската битка е в това! Много художници тържествуват инстинктивно, без да познават тази тема на изкуството. Вие рисувате една жена, но не я виждате“. Художникът е този, който фиксира и прави достъпно за най-„човечните“ хора зрелището, в което участват, без да го виждат.

Следователно няма изкуство на съгласието. Могат да се изработват обекти, доставящи удоволствие, като се свързват другояче вече готови идеи и се представят вече видени форми. Тази живопис или вторично слово е онова, което най-общо се разбира под култура. Художникът според Балзак или според Сезан не се задоволява да бъде култивирано животно, той поема културата още от нейното начало и наново я основава, говори, както е говорил първият човек, и рисува, сякаш никой никога не е рисувал преди него. Тогава изразяването не може да е превод на изяснена мисъл, понеже ясните мисли са тези, които вече са били изказани в нас самите или от другите. „Схващането“ не може да предшества „изпълнението“. Преди изразяването има само смътна треска и единствено създаденото и разбрано произведение ще докаже, че в него трябва да се открива по-скоро нещо, отколкото нищо. Тъкмо защото се връща, за да осъзнае това в дъното на немия и самотен опит, върху което дъно се градят културата и обменът на идеи, художникът изважда на бял свят своето произведение, както човекът е извадил от себе си първата дума, без да знае дали няма да е само вик, дали ще може да се откъсне от потока на индивидуалния живот, където се ражда, и да представи на същия този живот в неговото бъдеще или на съсъществуващите с него монади, а защо не и на отворената общност от бъдещи монади независимото съществуване на един установим смисъл. Смисълът на това, което ще каже худонжникът, не е никъде - нито в нещата, които още не са смисъл, нито в самия него, в неформулирания му живот. Той призовава от изградения вече разум, където се затварят „култивираните хора“, към разум, който би прегърнал собствените си източници. Когато Бернар иска да го върне към хорското разбиране, Сезан отговаря: „Аз се обръщам към разбирането на Всемогъщия Отец“. Във всеки случай той се обръща към идеята или проекта на един безкраен Логос. В основата им несигурността и самотата на Сезан се обясняват не с невротичната му природа, а с онова, към което тегли неговото творчество. Наследствеността може да му е дала богати усещания, завладяващи емоции, смътно чувство на тревога или тайнственост, които разстройвали волята на живота му и го откъсвали от хората; но тези дарове създават творба само в акта на изразяването и нямат никакво отношение спрямо трудностите, както и спрямо достойнствата на този акт. Трудностите на Сезан са трудностите на първата дума. Той е повярвал, че е безсилен, понеже не е бил всемогъщ, понеже не е бил Бог, а въпреки това е искал да изрисува света, да го превърне изцяло в зрелище и да покаже как ни докосва. Новата физична теория 
може да бъде доказана, защото идеята или смисълът ѝ е свързан чрез пресмятането с мерки от една област, която вече е обща за всички хора. Един творец като Сезан, художникът, философът трябва не само да създадат и да изразят дадена идея, но също да събудят начините, по които тя се преживява и които ще я вкоренят в други съзнания. Ако успее, творчеството притежава странната способност само̀ да учи на всичко. Следвайки посоченото от картината или книгата, изграждайки сравнения чрез сблъсък от едната и от другата страна, водени от смътната яснота на стила, читателят или зрителят накрая откриват онова, което някой е поискал да им съобщи. Художникът е успял само да съгради един образ. Трябва да се изчака образът да оживее за другите. Тогава произведението на изкуството ще е достигнало отделните животи, няма вече да съществува в само един от тях като упорита мечта или постоянен делириум или в пространството като оцветено платно - ще обитава неделимо множество умове, предполагаемо във всеки възможен ум като придобивка завинаги.

Така „наследственостите“, „влиянията“ - случайностите за Сезан - са текстът, който природата и историята му дават да дешифрира от своя страна. Те предоставят единствено буквалния смисъл на неговото творчество. Създанията на твореца, както впрочем свободните решения на човека, налагат на тази даденост фигуративен смисъл, който не е съществувал преди тях. Ако ни се струва, че животът на Сезан е носел в зародиш творчеството му, то е, защото познаваме най-напред творбите и през тях виждаме житейските обстоятелства, натоварвайки ги със смисъла, зает от творчеството му. Ако трябваше да фигурират в цялата тъкан от проекти, какъвто е бил самият Сезан, изброените житейски дадености, за които говорим като утежняващи обстоятелства, биха могли да го сторят само по един начин: предлагайки се като това, което има да изживее, и същевременно оставяйки неопределен начина на живот. В началото те са задължително положени, но обгръщащото съществуване заема тяхното място и те стават само монограм или емблема на живот, който свободно интерпретира сам себе си.

Нека обаче добре да схванем тази свобода. Да не си представяме някаква абстрактна сила, която би наложила въздействията си на житейските „дадености“ или би въвела разцепления в развитието. Със сигурност животът не обяснява творчеството, но е не по-малко сигурно, че те общуват. Истината е, че това творчество е изисквало точно този живот. Още отначало животът на Сезан намира равновесие, като се опира единствено на все още бъдещото творение, бидейки живот в проект, а творението съобщава за себе си чрез предизвестяващи знаци, които напразно бихме взели за причини, но които правят от творчеството и живота едно приключение. Тук вече няма причини и следствия, те се събират в симултанността на един вечен Сезан, който е формулата едновременно на това, което е искал да бъде, и това, което е искал да направи. Между шизоидното състояние и творчеството на Сезан има връзка, понеже самото творчество разкрива метафизичния смисъл на болестта - шизоидността като редукция на света до всички втвърдени привидности, като ценностите на изразяването остават висящи; тогава болестта престава да е абсурден факт и съдба, за да стане обща възможност за човешкото съществуване, когато то последователно се сблъсква с един от своите парадокси - феномена на изразяването. В този смисъл най-сетне да бъдеш Сезан и да бъдеш шизоиден е едно и също. Следователно не бихме могли да отделим творческата свобода от най-малко разсъдъчните поведения, които вече са давали знак за себе 
си в първите жестове на детето Сезан и в начина, по който нещата го докосвали. Смисълът, който Сезан ще придаде на нещата и лицата в картините си, му се е предлагал в самия свят по начина, по който светът се е явявал пред него, Сезан само го е освободил, същите неща и същите лица, както ги е виждал, са искали да бъдат нарисувани така и Сезан само е казал това, което те са искали да кажат. Но къде тогава е свободата? Вярно е, че обстоятелствата на съществуването могат да определят едно съзнание само когато то заобиколи основанията да съществува и оправданията, които си дава, можем да виждаме само пред нас и от гледна точка на целите, които сме ние, така че животът ни винаги е във формата на проект или избор и ни изглежда спонтанен. Но да кажем, че ние сме още отначало виждането на някакво бъдеще, означава да кажем също, че нашият проект е вече възпрян с първите ни начини на съществуване, че изборът вече е направен с първия ни дъх. Ако нищо не ни принуждава отвън, то е, защото сме всичко външно. Вечният Сезан, когото виждаме най-напред да изскача, който е привлякъл върху човека Сезан смятаните за външни нему събития и влияния и който е рисувал всичко, което го е застигало - дали това поведение спрямо хората и спрямо непреднамерено възприетия свят, свободен по отношение на външните причини, е свободно по отношение на самото себе си? Дали изборът не е отблъснат оттатък живота и има ли избор там, където все още няма поле от ясно очертани възможности, а има една-единствена вероятност като самотно изкушение? Ако аз още от раждането си съм проект, то е невъзможно да различа в мен дадено и създадено, следователно е невъзможно да посоча дори един жест, който да не е наследствен или вроден и който да не е спонтанен - ала също един-единствен жест, който да е абсолютно нов по отношение на онзи начин на съществуване в света, който съм аз още от началото. Това е същото като да се каже, че нашият живот е изцяло построен или е изцяло даден. Истинска свобода може да има само в хода на живота чрез преодоляване на нашата начална ситуация и същевременно без да престанем да бъдем същото - такъв е проблемът. Две неща са сигурни по отношение на свободата: никога не сме предопределени - и никога не се променяме, съответно винаги ще можем да намерим в миналото си предизвестието за това, което сме станали. Ние трябва да разберем двете неща едновременно и как свободата се ражда в нас, без да прекъсваме връзките си със света.

Връзки има винаги, дори и най-вече когато отказваме да се съгласим. По картините на Да Винчи Валери е описал едно чудовище на чистата свобода без любовници, без кредитор, без истории, без приключения. Никакъв блян не маскира за него самите неща, увереността му не се дължи на нищо подразбиращо се и той не чете съдбата си в някакъв привилегирован образ като пропастта на Паскал. Той не се е борил с чудовищата, разбрал е техните механизми, обезоръжил ги е с наблюдателността си и ги е свел до положението на познатите неща. „Няма нищо по-свободно, сиреч нищо по-нечовешко от разсъжденията му върху любовта и смъртта. Той ни позволява да ги отгатнем чрез няколко откъса в дневниците му. „Развихрената любов (казва приблизително той) е нещо тъй грозно, че човешкият род би угаснал - la natura si perderebbe, - ако онези, които иे се отдават, можеха да се видят отстрани“. Това пренебрежение личи от множество скици, понеже върховното презрение към някои неща се изразява в това най-сетне да ги разглеждаме на воля. Така той рисува тук- 
там анатомични сливания, двойки, които биха ужасили дори самата любов“". Той е майстор на своите похвати, прави каквото поиска, минава когато и както му хрумне от познанието към живота с върховна елегантност. Нищо не е направил, без да знае какво прави, и действието в изкуството му, също като действието на дишането или живота, не стои по-високо от наученото. Открил е „как да се държи в центъра“, откъдето е еднакво възможно да познава, да действа и да създава, защото действието и животът, станали упражнения, не са противоположни на откъсването в знанието. Той е „интелектуална мощ“, "човекът на духа“.

Да погледнем по-добре. За Леонардо няма откровение. Няма отворена пропаст от дясната му страна, казва Валери. Несъмнено. Но в „Света Анна, Девата и Детето“ има наметка на Девата, която обрисува лешояд и свършва срещу лицето на Детето. Има го фрагмента върху полета на птиците, където Да Винчи изведнъж прекъсва, за да последва спомен от детството: „Изглежда, съм бил предопределен да се занимая съвсем специално с лешояда, защото един от първите ми детски спомени е, че аз съм в люлката, над мен се спуска лешояд, отваря устата ми с опашката си и много пъти ме удря с тази опашка между устните ${ }^{\prime 3}$. Така дори това прозрачно съзнание има своята загадка - истински спомен от детството или фантазъм на зрялата възраст. Тя не тръгва от нищото, не се самоподхранва. Ето ни въвлечени в тайна история и гора от символи. Фройд иска да дешифрира загадката според онова, което се знае за значението на птичия полет, за фантазмите на fellatio и тяхното отношение към времето на кърменето, и това несъмнено предизвиква протест. Но най-малкото е факт, че за египтяните лешоядът е символ на майчинството, защото според вярванията им всички лешояди били женски и били оплождани от вятъра. Факт е също, че Отците на Църквата си служели с тази легенда, за да оборят чрез естествената история онези, които не искали да повярват в майчинството на девица. Възможно е в безкрайните си четения Леонардо да е срещал тази легенда. В нея откривал символа на собствената си съдба.

Той е бил незаконороден син на богат нотариус и в годината на раждането му бащата се жени за благородната дона Албиера, от която няма деца, така че прибира Леонардо в семейството, когато е на пет години. Следователно Леонардо е прекарал първите четири години с майка си, изоставената селянка, бил е дете без баща и се е запознал със света единствено в компанията на тази голяма и нещастна майка, която сякаш го е създала по чудо.

Ако днес си припомним, че името му не се свързва с никакви любовници и дори с никаква страст, че е бил обвинен в содомия, но е бил оправдан, че в записките му няма и дума за много други по-скъпи плащания, но с най-малките подробности са отбелязани разходите за погребението на майка му, а също и разходите за бельо и облекла за двама от неговите ученици, няма да сме далеч от истината, казвайки, че Леонардо е обичал една-единствена жена, майка си, и че тази обич е оставила място само за платоническа нежност към заобикалящите го момчета. През четирите решаващи години от детството си той е създал фундаментална привързаност, от която е трябвало да се откаже, когато е

\footnotetext{
2 Пол Валери. Въведение в метода на Леонардо да Винчи. Забележка и отклонение. - В: Човекът и раковинаma. С., 1988, с. 245. Превод от френски Христина Кочемидова. - Б. пр.

з Зигмунд Фройд. „Един детски спомен на Леонардо да Винчи“.
} 
бил извикан в семейството на баща си и е трябвало там да отнесе всички свои запаси от любов и цялата си способност да изоставя. Оставало му е единствено да използва жаждата си за живот в изследването и познанието на света, а понеже са го откъснали, е трябвало да стане онази интелектуална мощ, онзи човек на духа, чужденец сред хората, безразличен, неспособен за непосредствен гняв, любов или омраза, който оставял картините си недовършени, за да спечели време за странни експеритемнти, и в когото съвременниците му предусетили тайна. Всичко става, сякаш Леонардо никога не узрява съвсем, сякаш всички места в сърцето му са предварително заети, сякаш духът на изследването за него е бил начин да избяга от живота, сякаш е вложил в първите си години цялата сила на одобрение и сякаш до края е останал верен на своето детство. Той играел като дете. Вазари разказва, че „Леонардо направил тесто от някакъв восък и пътьом изработвал дребни животинчета, кухи отвътре, които литвали във въздуха, ако духнел вятър, но щом вятърът преставал, падали на земята. Друг път поставил на един гущер, намерен от лозаря на Белведере, люспи от други, одрани гущери, прикрепил му крила посредством течно сребро, които трепкали, докато се движел; поставил му рога и брада и го опитомил да стои в една кутия. Всичките му приятели, на които го показвал, побягвали от страх“4.

Той оставял произведенията си незавършени, както го е изоставил баща му. Не признавал авторитета и по отношение на познанието се доверявал само на природата и на собствената си преценка, както правят често тези, които не са били отгледани в страх и покровителствена власт на бащата. Оттук и чистата способност да изследва, самотата, любопитството, определящо ума, у Да Винчи се изграждат във връзка със собствената му история. На най-високата степен на свободата той пак е детето, което е бил, отделил се е от една страна само защото се е привързал другаде. Това, че става чисто съзнание, е още един начин да заеме позиция спрямо света и другите и този начин Да Винчи научава, нагърбвайки се със ситуацията, създадена от раждането и от детството му. Няма съзнание, което да не се носи от изначалното му ангажиране в живота и от начина на това ангажиране.

Онова, което може да е случайно в обясненията на Фройд, тук не дискредитира психоаналитичната интуиция. Неведнъж читателят се спира от недостатъчно доказателства. Защо това, а не друго нещо? Въпросът, изглежда, се налага, още повече че Фройд често дава множество интерпретации и всеки симптом според него е „свръхдетерминиран“. Ясно е най-сетне, че едно учение, което навсякъде намесва сексуалността, не би могло според правилата на индуктивната логика да установи нейната ефикасност където и да е, понеже се лишава от всеки противоположен опит, изключвайки предварително всеки разграничителен случай. Така психоанализата тържествува, но само на хартия. Защото внушенията на психоаналитика никога не могат да бъдат доказани, но не могат и да бъдат елиминирани: как да се припишат на случайността сложните сходства, които психоаналитикът открива между детето и възрастния? Как да отречем, че психоанализата ни е научила да възприемаме в един и друг момент от живота отгласи, алюзии, препратки, верижност, които не бихме и помислили да поставим под съмнение, ако Фройд коректно беше изградил

${ }_{4}^{4}$ Джорджо Вазари. Животът на Леонардо да Винчи. Флорентински живописеи и скулптор (1452-1519). С., 1980, с. 67. Превод Божан Христов. - Б. пр. 
теория за всичко това? Психоанализата не е създадена, за да ни даде, подобно на природните науки, необходимите отношения от причината към следствието, а за да ни посочи отношенията на мотивацията, които по принцип са просто възможни. Да не си представяме, че фантазният лешояд при Леонардо покрива инфантилното му минало и е силата, предопределила бъдещето му. По-скоро, също като словото на гадателя, това е двойствен символ, който отнапред се прилага към множество линии на възможни събития. По-точно: за всеки живот раждането и миналото определят фундаментални категории или измерения, които не налагат нито един акт в частност, но се четат или се откриват във всички. Независимо дали Леонардо се поддава на детството си, или иска да избяга от него, той е този, който винаги е бил . Решенията, които ни променят, във всеки случай се взимат с оглед на една фактическа ситуация, а фактическата ситуация може да бъде приета или отхвърлена, но не може да не ни осигури нашия порив и като ситуация за „приемане“ или „отхвърляне“ да бъде за нас въплъщение на ценността, която й придаваме. Ако целта на психоанализата е да опише този обмен между бъдеще и минало и да покаже как всеки живот се сънува над загадките, чийто краен смисъл никъде не е вписан предварително, няма защо от нея да се изисква индуктивна строгост. Херменевтичното съновидение на психоаналитика, който умножава комуникациите вътре в нас с нас самите, взима сексуалността за символ на съществуването и съществуването за символ на сексуалността, търси смисъла на бъдещето в миналото, а смисълът на миналото в бъдещето по-добре от всяка строга индукция се адаптира към кръговото движение на нашия живот, който обляга бъдещето си на миналото, миналото на бъдещето и където всичко символизира всичко. Психоанализата не прави свободата невъзможна, учи ни да я схващаме конкретно, като творческо възобновяване на самите нас и в крайна сметка винаги вярно на самите нас.

Следователно вярно е, че животът на един автор не ни учи на нищо, и същевременно, че ако съумеем да го прочетем, ще открием в него всичко, понеже е открит към творчеството. Също както наблюдаваме движенията на някое непознато животно, без да разбираме закона, който ги управлява, така свидетелите на Сезан не могат да отгатнат трансмутациите, които той налага на събитията и преживяванията, слепи са за неговото значение, за светлината, дошла отникъде, която го обгръща на моменти. Но той самият никога не е в своя център, девет от десет дни вижда около себе си единствено мизерията на своя емпиричен живот и пропилените опити, остатъци от непознат празник. Необходимо му е да осъществи свободата си - отново в света, върху платно, с цветове. От другите очаква одобрение, доказателство за своята ценност. Ето защо пита картината, която се ражда изпод ръката му, дебне чуждите погледи, отправени към платното му. Затова и никога не е престанал да работи. Ние никога не напускаме нашия живот. Никога не виждаме идеята, нито пък свободата лице в лице.

Maurice Merleau-Ponty. Sens et non-sens (1966)

(C) Превод от френски: Лидия Денкова

\footnotetext{
${ }^{5}$ Вазари пише: „Природата пожелала щедро да го надари и където и да обърнел мисълта, мозъка и душата си, показвал такава възвишеност в делата, че никой не му бил равен по съвършенство, схватливост, пъргавина, доброта, привлекателност и изящество“ ... „Ни една личност не донесла повече чест на изкуството от него“. (Вазари. Животът на Леонардо да Винчи, с. 14, 77. - Б. пр.)
} 